\title{
Pengaruh Terapi Musik Terhadap Penurunan Tingkat Kecemasan Anak Prasekolah Yang Mengalami Hospitalisasidi Paviliun Seruni Rsud Jombang
}

\author{
(The Effect Of Music Therapy To Decrease Anxiety Levels Pre-School Children Who \\ Experienced Hospitalization In Hospital Jombang Chrysan The Mum Pavilion)
}

\author{
Ana Farida Ulfa ${ }^{1)}$, Kurniawati ${ }^{2)}$ \\ Prodi D3 Keperawatan FIK UNIPDU Jombang \\ Email: anafaridaulfa@yahoo.com
}

\begin{abstract}
Hospitalizationis a process by which aplannedor emergency reasons, so the children had to be hospitalized can cause children to experience anxiety. To over come anxiety management can be given psychotherapy, one of which is with music therapy. The purpose ofthis study was todetermine the effect of music therapy to decrease anxiety levels preschool children who experienced hospitalization in Hospital Jombang Chrysan the mum Pavilion. This study uses the approach Quasy Experiment pretest-posttestdesign with control group. With a total sample of 14 children (2 groups) using purposive sampling technique. Data was collected through observation and then tabulated using data coding and tested using Mann Whitney and Wilcoxon with $\alpha=0.05$ significance level. The results of the analysis wilcoxon obtained $p$ valueof $0.015, p$ value $<\alpha(0.015<0.05)$ and MannWhitney obtained $p$ valueof $0.007, p$ value $<\alpha(0.007<0.05)$. So there is the effect of music therapy on reducing anxiety levels preschoolers who experienced hospitalization in Hospital Jombang Chrysan the mum Pavilion. The conclusion that can bedrawn from this studyis the effect of music therapy on anxiety levels pre-school children who experienced hospitalization in Hospital Jombang Chrysan the mum Pavilion.
\end{abstract}

Keywords: hospitalization, child anxiety, music therapy, pre-school age

\section{Pendahuluan}

Hospitalisasi pada anak merupakan proses karena suatu alasan yang berencana atau darurat mengharuskan anak untuk tinggal di rumah sakit menjalani terapi dan perawatan sampai pemulangan kembali kerumah.. Hospitalisasi merupakan salah satu penyebab stres baik pada anak maupun keluarganya, terutama disebabkan oleh perpisahan dengan keluarga, kehilangan kendali, perlukaan tubuh dan rasa nyeri (Nursalam, 2003).

Dampak dari hospitalisasi, anak akan mengalami kecemasan yang berujung terhadap prilaku maladaptifpada anak seperti menangis, berteriak, mencari orang tua menhindari dan menolak kontak dengan orang asing, menolak dilakukan perawatan, hingga menyerang perawat ata orang asing yang mendekat
(Wong,2009).Pada tahap perkembangan, perilaku maladaptif tersebut, anak mengalami gangguan pada perkembangan emosionalnya. Sehingga anak setelah di rawat dirumah sakit, tidak mau pisah dengan orang tuanya, dan bertahan dengan usia perkembanganya hingga saat ini (usia prasekolah) hingga dewasa. Selain itu, reaksi terhadap hospitalisasi, anak mencoba menghindar, tidak kooperatif, yang dapat mengganggu proses penyembuhan sehingga dapa memperlama anak untuk di rawat, yang mengakibatkan pembekakan biaya pengobatan (Elfira, 2011)

Selama ini banyak terapi yang dilakukan untuk meminimalkan atau menurunkan tingkat kecemasan misalnya terapi bermain, seperti permainan hospital story , clay therapy,yang dapat 
menurunkan kecemasan anak usia prasekolah.Pada penelitian tahun 2008, didapatkan pengaruh terapi musik terhadap kecemasan anak usia toodler, dengan respon kecemasan maladaptif pada kelompok terapi musik sebelum diberikan intervensi sebanyak 15 (100\%), dan sesudah dilakukan intervensi respon kecemasan maladaptif sebanyak 11 orang $(73,3 \%)$.

\section{Metode Penelitian}

Penelitian ini menggunakan desain Quasy - Eksperimental dengan desain Pretest - Posttest Control Group Design. Dalam penelitian ini variabel independennya adalah terapi musik, sedangkan variabel dependennya adalah respon kecemasan anak. Dalam penelitian ini, populasinya adalah seluruh anak usia pra sekolah(3-6tahun) yang dirawat di Paviliun Seruni RSUD Jombang. Teknik sampling yang digunakan adalah purposive sampling, sehingga didapatkan besar sampelnya adalah 14 responden dengan 7 responden untuk kelompok intervensi dan 7 responden untuk kelompok kontrol.

\section{Hasil Dan Pembahasan Hasil Penelitian}

Tabel 1 Tingkat kecemasan anak usia prasekolah sebelum diberikan terapi

\begin{tabular}{cccccc}
\hline No & Tingkat & \multicolumn{4}{c}{ Kelompok } \\
\cline { 3 - 6 } & Kecemasan & Kontrol & $\%$ & Perlakuan & $\%$ \\
\hline 1 & Tidak Ada & - & & - & \\
Kecemasan & $\begin{array}{c}\text { Kecemasan } \\
\text { Ringan }\end{array}$ & - & & - & \\
3 & $\begin{array}{c}\text { Kecemasan } \\
\text { Sedang }\end{array}$ & 2 & 28,6 & 2 & 28,6 \\
4 & $\begin{array}{c}\text { Kecemasan } \\
\text { Berat } \\
5\end{array}$ & 5 & 71,4 & 5 & 71,4 \\
\hline & Panik & - & & - & \\
\hline & Total & 7 & 100 & 7 & 100 \\
\hline
\end{tabular}

Data di atas menunjukkan bahwa tingkat kecemasan anak usia prasekolah yang mengalami hospitalisasi sebelum diberikan terapi sebagian besar responden dengan kategori tingkat kecemasan berat, hal itu dapat terlihat dari presentase yang diperoleh yaitu $71,4 \%$ pada kelompok perlakuaan dan 71,4\% kelompok kontrol.

Tabel 2 Tingkat kecemasan anak usia prasekolah sesudah dilakukan terapi musik dan health education

\begin{tabular}{|c|c|c|c|c|c|}
\hline \multirow{2}{*}{ No } & \multirow{2}{*}{$\begin{array}{c}\text { Tingkat } \\
\text { Kecemasan }\end{array}$} & \multicolumn{4}{|c|}{ Kelompok } \\
\hline & & Kontrol & $\%$ & Perlakuan & $\%$ \\
\hline 1 & $\begin{array}{l}\text { Tidak Ada } \\
\text { Kecemasan }\end{array}$ & - & - & 1 & 14,3 \\
\hline 2 & $\begin{array}{c}\text { Kecemasan } \\
\text { Ringan }\end{array}$ & - & & 3 & 42,9 \\
\hline 3 & $\begin{array}{c}\text { Kecemasan } \\
\text { Sedang }\end{array}$ & 3 & 42,9 & 3 & 42,9 \\
\hline 4 & $\begin{array}{c}\text { Kecemasan } \\
\text { Berat }\end{array}$ & 4 & 57,1 & - & - \\
\hline 5 & Panik & - & - & - & - \\
\hline & Total & 7 & 100 & 7 & 100 \\
\hline
\end{tabular}

Tabel di atas menunjukan bahwa tingkat kecemasan anak usia prasekolah yang mengalami hospitalisasi setelah diberikan terapi musik dan health education sebagian besar responden kelompok kontrol dengan kategori tingkat kecemasan berat, ini dapat terlihat dari presentase yang diperoleh yaitu $57,1 \%$ sedangkan pada kelompok perlakuaan sebagian besar dengan kategori tingkat kecemasan sedang dan ringan, ini dapat terlihat dari presentase yang diperoleh yaitu $(42,9 \%)$ dengan kategori kecemasan sedang, dan $(42,9 \%)$ dengan kecemasan ringan.

Tabel 3: Tabel hasil analisa pengaruh terapi musik terhadap tingkat kecemasan anak usia prasekolah yang mengalami hospitalisasi dengan menggunakan uji wilcoxon pre-post perlakuan.

\begin{tabular}{ccc}
\hline Uji & Kontrol & Perlakuan \\
Wilcoxon & $p=0,317$ & $p=0,015$ \\
\hline
\end{tabular}

Tabel 3 menunjukan bahwa uji Wilcoxon pada kelompok perlakuan $p=0,015$ (< 0,05) maka $\mathrm{H}_{0}$ ditolak dan $\mathrm{H}_{1}$ diterima yang menunjukan bahwa ada pengaruh yang signifikan antara sebelum dan sesudah perlakuan. Sedangkan pada kelompok kontrol $p=0,317(0,317>0,05)$, maka Ho diterima yang menunjukan tidak ada pengaruh yang signifikan antara 
sebelum dan sesudah diberi health education.

\section{Pembahasan}

Hasil penelitian menunjukan bahwa tingkat kecemasan anak usia sebelum diberikan perlakuan sebagian besar dengan kecemasan berat, baik pada kelompok perlakuan maupun pada kelompok kontrol. Faktor-faktor yang mempengaruhi hal ini adalah pengalaman, berdasarkan data sebagian besar responden baru pertama kali dirawat di rumah sakit, selain itu pada pada usia prasekolah hospitalisasi merupakan suatu hal yang menakutkan, ini dikarenakan anak harus berpisah dengan orang yang disayanginya, berpisah dari lingkungan yang dirasakannya aman, penuh kasih sayang, dan menyenangkan, yaitu lingkungan rumah, permainan, dan teman sepermainannya. Selain itu anak juga takut dengan lingkungan rumah sakit yang menakutkan, rutinitas rumah sakit, prosedur yang menyakitkan, dan takut akan kematian.

Tingkat kecemasan anak usia prasekolah pada kelompok perlakuan dan kelompok kontrol sesudah dilakukan terapi musik dan helath education. Tingkat kecemasan anak usia prasekolah yang mengalami hospitalisasi di Paviliun Seruni RSUD Jombang antara kelompok yang diberikan terapi musik dengan kelompok yang diberi health education mengalami perbedaan. Berdasarkan hasil penelitian, menunjukan bahwa tingkat kecemasan anak anak usia prasekolah yang mengalami hospitalisasi di Paviliun Seruni RSUD Jombang sesudah diberikan health eduction sebagian besar tidak mengalami penuruan, ini dapat dilihat pada tabel 2, hal ini menunjukan tidak ada perubahan yang signifikan. Sedangkan pada kelompok perlakuan, tingkat kecemasan anak mengalami penurunan, ini dapat dilihat pada tabel 2, ini menunjukan bahwa ada perubahan pada tingkat kecemasan anak setelah dilakukan terapi musik.
Analisa pengaruh terapi musik terhadap penurunan tingkat kecemasan anak usia pra sekolah yang mengalami hospitalisasi:

Peneliti melakukan uji wilcoxon dan uji mann-withney untuk menguji pada kedua kelompok perlakuan dan kontrol. Hasil penelitian ini menunjukan adanya pengaruh terpai musik terhadap penurunan tingkat kecemasan anak usia prasekolah yang mengalami hospitalisasi di Paviliun Seruni RSUD Jombang. Hal ini dapat dilihat pada tabel tabel 3 yang menunjukan bahwa uji Wilcoxon pada kelompok perlakuan $p=0,015(<0,05)$ maka $\mathrm{H}_{0}$ ditolak dan $\mathrm{H}_{1}$ diterima yang menunjukan bahwa ada pengaruh yang signifikan antara sebelum dan sesudah perlakuan. Sedangkan pada kelompok kontrol $p=0,317(0,317>0,05)$, maka Ho diterima yang menunjukan tidak ada pengaruh yang signifikan antara sebelum dan sesudah diberi health education.Dan uji Mann-Whitney pada pre-testp $=1,000$ $(>0,05)$. Hal ini menunjukkan bahwa nilai p> 0,05 yang berarti $\mathrm{H}_{0}$ diterima yang menunjukkan bahwa tidak ada pengaruh yang signifikan antara sebelum dan sesudah perlakuan terapi musik, sedangkan pada post-testp $=0,007(<$ $0,05)$. Hal ini menunjukkan bahwa nilai $p<0,05$ yang berarti $\mathrm{H}_{0}$ ditolak dan $\mathrm{H}_{1}$ diterima yang menunjukkan bahwa ada pengaruh yang signifikan antara sebelum dan sesudah perlakuan terapi musik.

Perbedaan tingkat kecemasan anak pada kelompok kontrol dan kelompok perlakuan ini dikarenkan pada kelompok kontrol saat responden diberi health education anak hanya monoton mendengarkan dan tidak jarang anak tidak menghiraukan. Hal ini karena anak lebih cenderung meyakini tentang persepsi dirumah sakit, bahwasanya rumah sakit adalah lingkungan yang menakutkan, dan anak menganggap tindakan dan prosedurnya mengancam integritas tubuhnya.

Menurut Nyswander dalam Machfoedz dan Suryani (2006). 
Pendidikan kesehatan adalah suatu proses perubahan diri manusia yang ada hubungannya dengan tercapainya tujuan kesehatan perorangan dan masyarakat. Menurut Steward dalam WijayantiM. $\mathrm{T}(2011)$, pendidikan kesehatan adalah unsur kesehatan dan kedokteran yang didalamnya terkandung rencana untuk mengubah perilaku perseorangan dan masyarakat dengan tujuan untuk membantu program pengobatan, rehabilitasi, pencegahan penyakit dan peningkatan kesehatan.

Sedangkan pada kelompok perlakuan mengalami penurunan tingkat kecemasan yang signifikan, hal ini karena di dalam musik terdapat 3 komponen penting yang mampu membuat perasaan tenang yaitu melodi, ritem dan harmonisasi.

Melodi merupakan alunan nada yang merupakan vibrasi suara yang timbul dari semua jenis alat musik. Ritem adalah satuan kunci nada yang mengikuti melodi dengan mengambil bagian bagian tertentu sesuai dengan tempo dan ketukan yang berbeda-beda. Sedangkan harmonisasi ialah kebersamaan dan keselarasan dari seluruh komponen suara/ nada, baik itu suara, kunci nada, tempo, hingga volume.

Dari 3 komponen tadi akan menghasilkan vibrasi suara yang mengalun melalui gendang telinga diterima oleh system saraf pusat melalui syaraf auditori lalu hipotalamus mengeluarkan hormon ptiutari sehingga endorphin meningkat mengakibatkan rasa rileks, fly, nyeri menurun, senang, tenang sehingga mekanisme koping anak adaptif dan tingkat kecemasan turun. Hal ini yang menyebabkan anak merasa tenang dan meknisme koping anak adaptif. Musik menghasilkan rangsangan ritmis yang kemudian ditangkap melalui organ pendengaran dan diolah di dalam sistem saraf tubuh dan kelenjar pada otak yang selanjutnya mereorganisasi interpretasi bunyi ke dalam ritme internal pendengarnya. Ritme internal ini mempengaruhi metabolisme tubuh manusia sehingga prosesnya berlangsung dengan lebih baik. Dengan metabolisme yang lebih baik, tubuh akan mampu membangun sistem kekebalan yang lebih baik, dan dengan sistem kekebalan yang lebih baik tubuh menjadi lebih tangguh terhadap kemungkinan serangan penyakit (Satiadarma, 2002)

\section{Kesimpulan}

1. Sebelum diberikanperlakuan baik dari kelompok perlakuan dan kontrol tingkat kecemasan sebagian besar kategori kecemasan berat. Hal ini disebabkan anak merasa asing terhadap lingkungan sekitar selain itu juga karena perpisahan dan kehilangan kontrol (Wong\& whaley, 2007).

2. Sesudah perlakuan responden pada kelompok perlakuan tigkat kecemasan mengalami penurunan. Sedangkan pada kelompok kontrol mayoritas tidak mengalam penurunan, meskipun ada yang mengalami penurunan yaitu 1 anak. Hal ini dikarenakan vibrasi musik yang mengalun melalui gendang telinga diterima oleh system saraf pusat melalui syaraf auditori lalu Hipotalamus mengeluarkan Hormon Ptiutari sehingga endorphin meningkat mengakibatkan rasa rileks, fly, nyeri menurun, senang, tenang sehingga mekanisme koping anak adaptif dan tingkat kecemasan turun.

3. Pebedaan antara kelompok perlakuan dan kontrol menunjukkan adanya pengaruh yang signifikan pada kelompok perlakuan, hal ini membuktikan bahwa ada pengaruh terapai musik terhadap penurunan tingkat kecemasan anak usia pra sekolah.

\section{Daftar Pustaka}

Arikunto, Suharsini, Prrof, Dr (1998). Prosedur Penelitian Suatu Pendekatan Praktek. Edisi Revisi IV. Jakarta: Rineka Cipta. 
Hawari, D. (2004). Manajemen stress, cemas dan depresi. Jakarta: FK UI.

Hidayat A. Aziz Azimul, Skep, Ners (2005). Pengantar Ilmu KeperawatanAnak 1. Edisi I. Jakarta: Salemba Medika.

Hockenberry, M. J., \& Wilson, D. (2007). Wong's nursing care of infants and children (8th ed.). St. Louis: Mosby Elsevier.

Kaplan, H.I \& Sadock, B. J. (2002). Sinopsis psikiatri jilid 2. Jakarta: Binarupa Aksara.

Nursalam (200). Konsep dan Penerapan Metode Penelitian Ilmu Keperawatan : Pedoman Skripsi, Tesis dan Instrumen Penelitian Keperawatan .Jakarta: Salemba Medika.

Potter \&Perry. (2005). Buku ajar fundamental keperawatan volume 1 , Edisi 4. Jakarta: EGC

Sari, F. S., \& Sulisno, Madya. (2012). Hubungan kecemasan ibu dengan kecemasan anak saat hospitalisasi anak. Journal Nursing Study. Volume 1, Nomor 1, Tahun 2012.

Satiadarma, M.(2002). Terapi musik, Cetakan Pertama. Jakarta: Milenia Populer.

Stuart, G.W \& Sundeen, S.J. (1998). Keperawatan jiwa, Edisi 3. Jakarta: EGC.

(2001). Buku saku keperawatan jiwa(edisi ketiga). Jakarta: EGC.

Supartini, Y (2004). Editor : Monica Ester. Buku Ajar Keperawatan Anak. Jakarta: EGC.
Tomb, D. A. (2004). Buku saku psikiatri edisi keenam. Jakarta: EGC.

Wong , D. L (2012). Editor : Sari Kurniaingsih. Alih Bahasa : Monica Ester. Pedoman Klinis Keperawatan pediatrik (Wong And Whaley's Clinical Manual of Pediatric Nursing). Edisi 4. Jakarta: EGC.

Wong dan Whaley's. (2007). Nursing care of infants and children, 8th edition. St 